\title{
EFFICIENCY ASSESSMENT OF WASTEWATER TREATMENT PLANT: A CASE STUDY OF PATTOKI, DISTRICT KASUR, PAKISTAN
}

\author{
${ }^{1}$ MS candidate, Department of Civil Engineering, KFUEIT, RYK Pakistan \\ ${ }^{2}$ Assistant Professor, Khwaja Fareed University of Engineering \& Information Technology, Rahim Yar Khan \\ ${ }^{3}$ Lecturer, Department of Civil Engineering, University of Lahore, Pakistan \\ *Corresponding Author E-mail : yasir.niaz.kfueit.edu.com
}

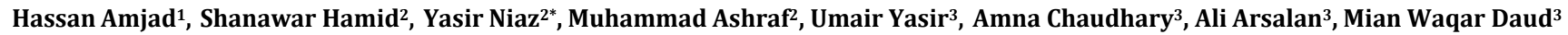

This is an open access article distributed under the Creative Commons Attribution License, which permits unrestricted use, distribution, and reproduction in any medium, provided the original work is properly cited.

\section{ARTICLE DETAILS}

\section{Article History:}

Received 21 August 2019

Accepted 23 September 2019

Available online 2 October 2019

\section{ABSTRACT}

Pakistan being an agricultural country greatly depends on the water. Intense agriculture and ever-increasing population growth have created stress on the limited water resources of the country. Therefore, use of industrial discharge effluent and sewage water for irrigation is a common practice. Realizing the situation of safe disposal of wastewater in Pattoki to minimize the public risks of indiscriminate disposal of wastewater, Punjab government and Korea International Cooperation Agency (KOICA) constructed a wastewater treatment plant at Pattoki district Kasur. The purpose of this study is to check the efficiency of wastewater being treated by the treatment plant in compliance with the National Environmental Quality Standards (NEQS) and to check the efficiency of functional components of treatment plant. Water samples were collected from various points of the treatment plant in order to perform various onsite and laboratory test (DO, BOD, COD, Chloride, TSS, and PH) to check the efficiency of the wastewater treatment plant. The results obtained for each water quality parameters (physical, chemical, and biological) were compared with National Environmental Quality Standards (NEQS). The recommended value of DO was greater than $2 \mathrm{mg} /$ liter, BOD ${ }_{5}, \mathrm{COD}$, Chlorides, TSS and PH by PEQS were less than $80 \mathrm{mg} / \mathrm{liter}, 150 \mathrm{mg} / \mathrm{liter}$, $1000 \mathrm{mg} / \mathrm{liter}, 150 \mathrm{mg} /$ liter and 6.5-9 respectively. The measured values of DO, BOD 5 , COD, Chlorides, TSS and PH were $0.3 \mathrm{mg} /$ liter, $310 \mathrm{mg} / \mathrm{liter}, 48 \mathrm{mg} / \mathrm{liter}, 1760 \mathrm{mg} / \mathrm{liter}, 204 \mathrm{mg} / \mathrm{liter}$ and 8.3 respectively. The values of DO, BOD $_{5}$ and TSS are not within PEQS recommended range. More facultative and anaerobic ponds should be constructed in order to treat total wastewater generated in Pattoki, as present plant is treating almost one fourth of total wastewater generated in Pattoki. Aerators should be provided at the aerobic ponds for improving the efficiency of wastewater treatment plant. Effluent from the treatment plant can be used for floriculture conjunctively with fresh water. Moreover, the concentration of physio-chemical parameters in the effluent also decreases after mixing the water available in drain. To some extent it also reduces the infiltration of dangerous components (as drain is not lined with concrete) present in wastewater that may contaminate the ground water or may have hazardous effects on quality of soil present in field. However, further studies are required to evaluate chemical parameters or heavy metals like arsenic, fluorides, chromium, zinc etc.

\section{KEYWORDS}

Biological Wastewater treatment, Industrial Effluent, KOICA, Wastewater. anaerobic pond. Anaerobic ponds are normally desludged after a period of 5 years. The facultative ponds usually come after anaerobic ponds to further polish the effluent. In facultative ponds both bacteria aerobic and anaerobic treat the wastewater. Facultative ponds reduce the level of BOD to such a level that it can now be disposed to water bodies. In aerobic zone of facultative ponds, bacteria and algae exist in mutually beneficial or symbiotic relationship. Algae produce oxygen during photosynthesis which is consumed by bacteria to metabolize the organic matter, whereas bacteria releases carbon dioxide and other inorganic matter like nitrogen and phosphorus which are needed by algae to grow and meet the food requirement. Hence under normal light the metabolic action of these two microbial groups complement each other. BOD removal in facultative pond is usually in range of $70-80 \%$ based on unfiltered samples. The maturation ponds are used to reduce the fecal coli form count in the wastewater. Maturation ponds are aerobic throughout the depth. If more fecal coli form reduction is required, then more maturation ponds are provided in series. Under such conditions all the maturation ponds are equally sized, and this is the most efficient configuration. 
Treatment ponds have been used to treat wastewater for many years, particularly as wastewater treatment systems for small communities. Many terms have been used to describe the different types of systems employed in wastewater treatment. Oxidation pond has been widely used as a collective term for all types of ponds. Originally, an oxidation pond was a pond that received partially treated wastewater, whereas a pond that received raw wastewater was known as a sewage lagoon [1]. Oxidation (stabilization) pond is a simple scientifically designed pond with 2-6 feet depth, where BOD5 reduction of a wastewater takes place by supporting algal-bacterial growth these ponds are effective, low-cost and simple technology for the treatment of wastewater before it is discharged to an aquatic ecosystem, and are commonly used in warm climates to purify wastewater. The performance of pond depends on climatological conditions like light, temperature, rain, wind and also the wastewater quality [2]. The oxidation pond receives flows that have passed through a stabilization pond or primary settling tanks. This type of pond provides biological treatment, additional settling and some reduction in the number of fecal coliform present. An oxidation pond is normally designed using the same criteria as the stabilization pond [3]. Oxidation pond typically operate in an extended aeration mode with long detention and solids retention time and is a widely adopted technique for the treatment of domestic and trade wastes. It is one of the methods used extensively in the tropical areas of the world for treating the wastewater [4]. Hospital wastewaters have been reported to be best treated in the oxidation pond. Oxidation pond comprises different groups of organisms such as bacteria, algae, protozoa, fungi, viruses, rotifers, nematodes, insects and crustacean larvae etc. These organisms coexist and compete with each other. The bacteria present in the pond decompose the biodegradable organic matter and release carbon dioxide, ammonia and nitrates. These compounds are utilized by the algae, which together with sunlight and photosynthetic process releases oxygen, enabling the bacteria to breakdown more waste and accomplish reduction in $\mathrm{BOD}_{5}$ levels [5].

In Pakistan, the wastewater domestic and industrial is directly disposed to sewer lines, a natural drain or water body, a nearby field or an internal septic tank. Mostly, wastewater of Islamabad and Karachi are treated and dispose, and the wastewater of other cities is not treated to any biological treatment process. Even these two cities treat only a small proportion (less than $8 \%$ ) of their wastewater before disposal [6]. Pakistan has become a water deficit country now a days. The water availability in 1996 is 1,299 $\mathrm{m}^{3}$ per capita which decreases to $1,100 \mathrm{~m}^{3}$ are per capita in 2006 . Now it is projected to decrease $700 \mathrm{~m}^{3}$ per capita in 2025. Therefore, wastewater, and other non-conventional water resources has become important to treat and use for irrigation purpose. In Pakistan, the wastewater domestic and industrial is directly disposed to sewer lines, a natural drain or water body, a nearby field or an internal septic tank. Mostly, wastewater of Islamabad and Karachi are treated and dispose, and the wastewater of other cities is not treated to any biological treatment process. Even these two cities treat only a small proportion (less than 8\%) of their wastewater before disposal. The increase in population will have a direct impact on the water-sector for meeting the domestic, industrial and agricultural needs. Pakistan has now essentially exhausted its available water-resources and is on the verge of becoming a water-deficit country. The quality of groundwater and surface-water is low and is further deteriorating because of unchecked disposal of untreated municipal and industrial wastewater and excessive use of fertilizers and insecticides. Water quality monitoring and information management is lacking, even though it's crucial to any water-quality improvement Programme [7].

Various investigations and surveys indicate that water-pollution has significantly increases. The pollution-levels are higher particularly in and around the big cities of the country where clusters of industries have been established. The water-quality deterioration problems are caused by the discharge of hazardous industrial wastes, including persistent toxic synthetic organic chemicals, heavy metals, pesticides and municipal wastes and untreated sewage water into natural waterbodies. These substances mixed with water then cause widespread water-borne and water-washed diseases [8]. The Lahore, country's second largest city, disposed-off about $28 \mathrm{~m}^{3}$ / $\mathrm{sec}$ wastewater in 2006 into the River Ravi without any treatment. The river pollution is frequently associated with the disposal of untreated effluents from municipal, industrial and agricultural wastes into the natural streams, which is always considered as an easy way to dispose-off many kinds of effluents. The people's psychology is that the wastes are washed away and are not visible after dumping [9]. Therefore, the objectives of the study are to assess the efficiency of the wastewater treatment plant and characteristics of the physio-chemical parameters in disposal drain of the wastewater treatment plant in Pattoki, District Kasur.

\section{METHODS}

\subsection{Physical parameters}

$\mathrm{Ph}$ was determined in the field directly with PH meter by taking the onsite samples at different stages of treatment in WWTP. Similarly, temperatures were taken with thermometers placed at different points and electrical conductivity was checked. Turbidity was checked by turbidity meters. All the parameters were checked after the proper calibration of instruments.

\subsection{Chemical parameters}

BOD $_{5}$ was analyzed in laboratory by standard method. Each sample was poured in 9 BOD bottles ( 3 with $5 \mathrm{ml}, 3$ with $10 \mathrm{ml}, 3$ with $20 \mathrm{ml}$.) for every stage of treatment. DO of three bottles of each sample was checked same day for zero day DO. Other bottles were kept in incubator with $20^{\circ} \mathrm{C}$ for 5 days. Then DO was checked after 5 days and BOD was determined with Formula.

$$
B O D_{5}=\frac{D_{0}-D_{5}}{\text { sample Volume in ml. }}
$$

Where,

$D_{0}=$ Dissolves oxygen for zero day

$D_{5}=$ Dissolves oxygen after 5 days

COD was also determined with by the titration process using ferrous ammonium sulfate (FAS) as a reducing agent. The formula below was used to determine the value of COD

Where,

$$
\operatorname{COD}(\mathrm{mg} / \mathrm{lit})=\frac{(B-A) \times N \times 8000}{\text { Vol. }(\mathrm{ml}) \text { of the sample }}
$$

$A=$ Titrant volume (ml) for blank

$B=$ Titrant Volume (ml) wastewater

$N=$ Normality of ferrous ammonium solution i.e. $0.25 \mathrm{~N}$

\section{STUDY AREA AND WWTP DESCRIPTION}

The study area was specially selected due to certain parameters, such as the geometric growth of the population and infrastructure development in the city. The performance evaluation of WWTPs was carried out based on the following criteria: PH, Temperature, Turbidity, Total Suspended Solids (TSS), Biological Oxygen Demand (BOD 5 ) and Chemical Oxygen Demand (COD), Dissolved Oxygen (DO), chlorides. Few tests like PH, Temperature and Turbidity were performed in field and for other test, samples were collected after every treatment step from various points in the WWTP, i.e. raw sewage at the grit chamber, in the inlet box, influent of each anaerobic ponds, Influent at each facultative ponds, upstream and downstream of drain, for laboratory analysis (Figure 1). The average values were considered for further decision-making processes. Samples were preserved at $4^{\circ} \mathrm{C}$ when transporting them to the laboratory. They were analyzed for Chemical Oxygen Demand (COD), Biochemical Oxygen Demand $\left(\mathrm{BOD}_{5}\right)$.

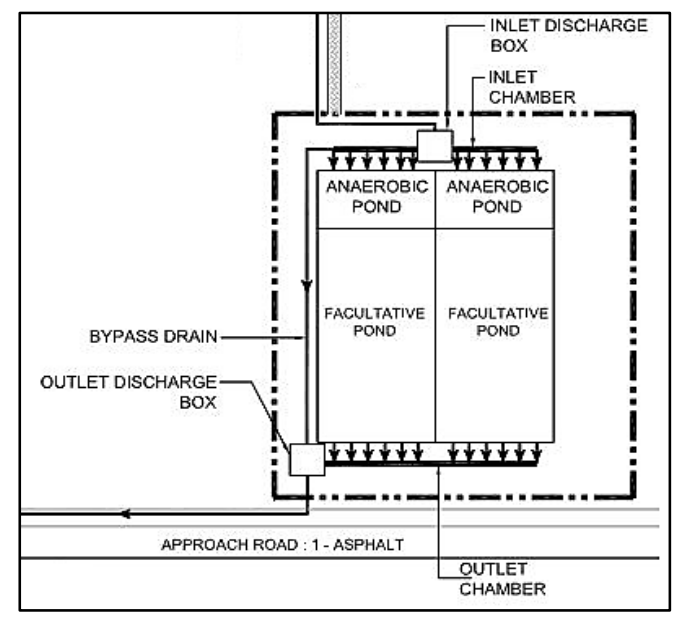

Figure 1: Layout of Wastewater Treatment Plant 
Pattoki city is situated at about 80-km from Lahore on Lahore Multan road. It is also connected by Lahore- Karachi main Railway line. It is central marketplace for vast agricultural products and for agro-based industries. Several rice mills and oil factories are functioning in the city. One sugar mill named Pattoki Sugar Mill is working in the out skirts of the city. The city has been developing very rapidly both industrial and population wise during recent past.

Pattoki Minor is an irrigation canal and is located in Punjab, Pakistan. The estimate terrain elevation above sea level is 199 meters. For maintaining the quality standards of wastewater Government of Punjab has formed EQS in 2012.

The wastewater Treatment plant is an extension of the existing PHED pump station being operated by the TMA staff Pattoki. The purpose of the plant is to treat all municipal wastewater of Pattoki town. When any of the five pumps installed on the pump station starts pumping wastewater, wastewater treatment plant (WWTP) will start receiving this water through inlet pipe. From inlet pipe the water will enter the Anaerobic Ponds through inlet chamber and start accumulating in the anaerobic ponds till the water reaches the level of connecting drains. From connecting drains, the water will start entering the Facultative ponds till the water level in both the ponds become same and treated water is ready to go out from the outlet drains in the Outlet chamber. The wastewater treatment plant is an extension of the existing PHED pump station being operated by the TMA staff Pattoki. The purpose of the plant is to treat all municipal wastewater of pattoki town. To achieve this purpose, a proper understanding of its working is essential for those involved in the operation and maintenance of this facility. The wastewater treatment plant is divided into two main sections. First, the pump station where 10 valves are installed on the 5 pumps each with capacity and almost all operating activities are initiated and regulated here. Second, the inlet pipe that transport the wastewater into the water stabilization ponds. When any of the five pumps installed on the pump station starts pumping wastewater WWTP starts receiving this water through inlet pipe. From inlet pipe the water enters the anaerobic ponds through inlet chamber and starts accumulating in the anaerobic ponds till the water reach the level of connecting drains. From the connecting drains the water starts entering the facultative pond till the water level in both the ponds become same and the treated water is ready to go out from the outlet drains in the outlet chamber.

Except for pumping water in the inlet box, all the water runs under gravity flow without any external involvement. The levels are maintained in different hydraulic structures is such that it minimizes human intervention. Similarly, the treatment process itself is dependent on natural elements i.e. oxygen, sunlight etc. and does not require human interference.

Table 2: Water quality parameters along with PEQS standard values.

\begin{tabular}{|c|l|l|l|l|l|l|l|}
\hline Tested parameters & $\begin{array}{l}\text { Grit } \\
\text { chamber }\end{array}$ & $\begin{array}{l}\text { Anaerobic } \\
\text { influent }\end{array}$ & $\begin{array}{l}\text { Facultative } \\
\text { influent }\end{array}$ & $\begin{array}{l}\text { Facultative } \\
\text { effluent }\end{array}$ & $\begin{array}{l}\text { Drain at } \\
\text { upstream }\end{array}$ & $\begin{array}{l}\text { After 500 } \\
\text { meters }\end{array}$ & PEQS \\
\hline Do & 0.3 & 0.1 & 0.05 & 0.03 & 0.02 & 0.3 & $>2$ \\
\hline COD (mg/lit) & 2000 & 1100 & 1000 & 240 & 48 & 132 & 150 \\
\hline BOD (mg/lit) & 1470 & 855 & 780 & 320 & 220 & 310 & 80 \\
\hline Chloride (mg/lit) & 2340 & 2340 & 2340 & 2340 & 2340 & 2340 & 1000 \\
\hline TSS (mg/lit) & 398 & 385 & 294 & 111 & 82 & 204 & 150 \\
\hline Ph & 8.2 & 7.9 & 8 & 8.1 & 8.2 & 8.3 & $6.5-9$ \\
\hline
\end{tabular}

The bold values in the table represents the values that are within the prescribed limits of PEQS. In second last column (Drain after 500 meters) we can clearly observe a rise in every value as compared to samples taken at drain before mixing because the effluent of the WWTP is released in the drain that carries untreated part of wastewater that exceeds the capacity of treatment plant. Table 2 also represents that upon mixing of the treated wastewater from WWTP with untreated wastewater there is a great decrease in value of final mixture which means that water in the drain is better in quality than that of influent of WWTP and is less hazardous.

\subsection{Physical, chemical and biological quality of wastewater samples drawn from grit chamber and drain after mixing}

Table 2 shows the results of physical, chemical and biological parameters
Table 1: Design parameters of WWTP Pattoki.

\begin{tabular}{|l|c|c|}
\hline Parameter & Unit & Quantity \\
\hline Flow of Pattoki & $\mathrm{m}^{3} /$ day & 9000 \\
\hline Total area of stabilization pond & Acres & 50 \\
\hline Total pumps & No. & 5 \\
\hline 2 small pumps & Cusec & 5 \\
\hline 3 large pumps & Cusec & 10 \\
\hline Pipes and valves for small pumps & Inch & 14 \\
\hline Pipes and valves for large pumps & Inch & 20 \\
\hline Inlet pipes & Inch & 20 \\
\hline Anaerobic ponds & & \\
\hline Detention Time & Days & $1-5$ \\
\hline Total volume & $\mathrm{m}^{3}$ & 10395 \\
\hline $\begin{array}{l}\text { Wastewater depth in anaerobic } \\
\text { ponds }\end{array}$ & $\mathrm{M}$ & 4.0 \\
\hline Free board & $\mathrm{M}$ & 0.5 \\
\hline Total depth & $\mathrm{M}$ & 4.5 \\
\hline Mid depth area of anaerobic ponds & $\mathrm{m}^{2}$ & 2599 \\
\hline Side slopes & Vertical: & $1: 3$ \\
\hline Length: Width ratio & & $1: 2$ \\
\hline Top Length & $\mathrm{M}$ & 51.05 \\
\hline Top Width & $\mathrm{M}$ & 87.09 \\
\hline Bottom Length & $\mathrm{M}$ & 24.05 \\
\hline Bottom width & $\mathrm{M}$ & 60.09 \\
\hline Top area of anaerobic pond & $\mathrm{m}^{2}$ & 4445.86 \\
\hline Facultative pond & & \\
\hline Detention Time & Days & $2-12$ \\
\hline Total volume & $\mathrm{m}^{3}$ & 41538 \\
\hline $\begin{array}{l}\text { Wastewater depth in facultative } \\
\text { ponds }\end{array}$ & $\mathrm{M}$ & 2.0 \\
\hline Free board & $\mathrm{M}$ & 0.5 \\
\hline Total depth & $\mathrm{M}$ & 2.5 \\
\hline Mid depth area of facultative ponds & $\mathrm{M}$ & 20769 \\
\hline Side slopes & $\mathrm{Mertical}$ \\
\hline Top Length & $1: 3$ \\
\hline Top Width & $\mathrm{M}$ & 274.95 \\
\hline Bottom Length & $\mathrm{M}$ & 87.09 \\
\hline Bottom width & $\mathrm{M}$ & 259.95 \\
\hline Top area of anaerobic pond & 23946.6 \\
\hline & & \\
\hline & & \\
\hline
\end{tabular}

\section{RESULTS AND DISCUSSIONS}

Wastewater quality of six samples from different points of wastewater treatment plant Pattoki were analyzed and results obtained for each water quality parameters (physical, chemical and biological) were compared with Punjab Environmental Quality standards (PEQS) guideline values. Results obtained for each wastewater quality parameter of samples is shown in the table 2 . \begin{tabular}{l|l|l|l}
8.1 & 8.2 & 8.3 & $6.5-9$ \\
\hline
\end{tabular} Generally, the treatment plant brought down the $\mathrm{BOD}_{5}$ value from 1470 $\mathrm{mg} / \mathrm{lit}$ to $310 \mathrm{mg} / \mathrm{lit}$. The removal of $\mathrm{BOD}_{5}$ was not met to the prescribed value $80 \mathrm{mg} / \mathrm{lit}$. And also decrease the COD value from $2000 \mathrm{mg} / \mathrm{lit}$ to 132 $\mathrm{mg} / \mathrm{lit}$ which meet to prescribe value $150 \mathrm{mg} / \mathrm{lit}$. The value of chlorides remained same throughout the process and did not meet the standard value that is $1000 \mathrm{mg} / \mathrm{lit}$. Total suspended solids (TSS) decrease from 398 $\mathrm{mg} / \mathrm{lit}$ to $204 \mathrm{mg} / \mathrm{lit}$ the removal of TSS was not met to the standard value $150 \mathrm{mg} / \mathrm{lit}$. In the physical parameter Ph values meet the prescribed value $6.5-9$.

\subsection{Efficiency of Anaerobic Ponds}

Figure 2 shows the efficiency of anaerobic ponds of physio-chemical parameters. Generally, values of all parameters were decreased slightly 
after leaving the anaerobic ponds except chlorides. Non-significant in values of COD, BOD as only anaerobic decomposition of matter is done here quickly. The value of TSS also shows a minor reduction as the slope of anaerobic pond is greater hence reduces the detention time of wastewater in pond that ultimately caused the slow settlement of suspended solids under gravity.

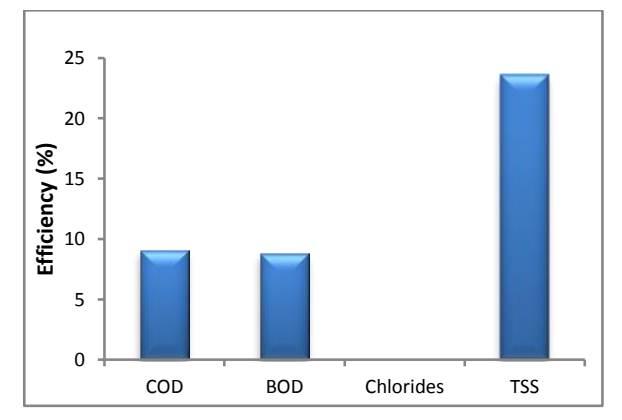

Figure 2: Efficiency of Anaerobic Pond

\subsection{Efficiency of Facultative Ponds}

As the effluent enters into the facultative pond, aerobic and anaerobic decomposition processes start that cause the reduction of COD and BOD. Moreover, due to greater detention time of effluent in pond cause the settlement of suspended solids hence removal of TSS occurs better than anaerobic pond as given in figure 3 .

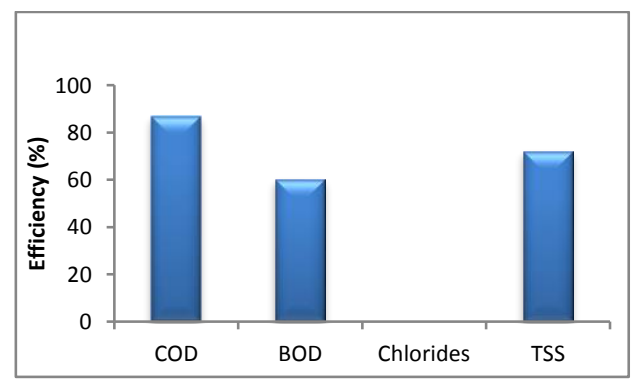

Figure 3: Removal Efficiency of Facultative Pond

\subsection{Efficiency of treatment plant}

Figure 4 shows the efficiency of the treatment plant. Almost $97.6 \%$ removal efficiency is accomplished in COD. The removal efficiency of BOD 5 and total suspended solids (TSS) is achieved less than $80 \%$. As no chemical treatment is being done to remove chlorides from wastewater so value of chloride remains same throughout the WWTP.

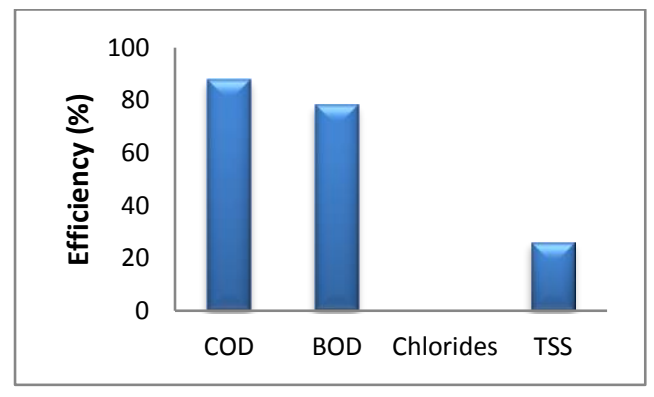

Figure 4: Efficiency of Wastewater Treatment Plant.

Physio-chemical parameters i.e., COD, BOD, Chlorides and TSS are not within the prescribed limits as define by PEQS. Because the ponds have limited capacity for fully accomplish these parameters. Therefore, the effluent from the treatment plant is not fully safe to dispose. However, while flowing through the drainage channel the COD and BOD reduces and approaches to the limits described by PEQS. The drain is lined hence lower chance of groundwater quality deterioration. Moreover, the existing capacity of the waste water treatment plant is not sufficient to treat whole effluent from disposal station. Therefore, some portion of effluent is directly added into the drainage channel.

\section{CONCLUSIONS AND RECOMMENDATIONS}

Study was carried out to determine the efficiency of wastewater treatment plant in the city of Pattoki, District Kasur, Pakistan. Following conclusions can be drawn from the results:

The value of DO was significantly less than the prescribed limit of PEQS which ultimately affected the removal of biodegradable organisms. Therefore, effected the removal of Wastewater treatment plant efficiently decreased the COD and BOD5 to some extent but could not approach the safe limits. The removal efficiency of COD is almost $88 \%$. However, the value is $60 \%$ more than the criteria define by PEQS.

The value of $\mathrm{BOD}_{5}$ and TSS were also more than the prescribed limits of PEQS. The removal efficiency of $\mathrm{BOD}_{5}$ and TSS is about $80 \%$ and $26 \%$, respectively. However, values of BOD 5 and TSS were 400 and 200 times more than the prescribed limits.

Moreover, the physio-chemical parameters values reduced after flowing through a channel but still require some treatment to approach safe limits.

Therefore, it is suggested that total wastewater generated at Pattoki city should be treated at the treatment plant by providing more facultative and anaerobic ponds. Aerobic and maturation ponds should be constructed to control DO. Extended aeration system should be installed by providing aerators at the bottom for more efficient BOD5 removal. Coagulation process may be implemented to decrease TSS to the recommended limit. Better treatment of wastewater can be done by providing trickling filters and biological contractors. Also, a fully equipped lab should be constructed for testing various physical, chemical and biological parameter of wastewater and accordingly maintaining the efficiency of the plant as of PEQS. Study can be conducted to evaluate chemical parameters or heavy metals like arsenic, fluoride, chromium, zinc etc, and to check the feasibility for reuse of treated wastewater.

\section{ACKNOWLEDGEMENTS}

The work reported in this paper was carried out in Water Quality Laboratory, Department of Civil Engineering, University of South Asia Lahore, Pakistan. I express my gratitude to Engr. Dr. Haroon Rashid, HoD, Department of Civil Engineering, Khwaja Fareed University of Engineering and Information Technology for his technical guidance to enhance the quality of the research work.

\section{REFERENCES}

[1] Mackenzie, L.D. 2010. A handbook of introduction to environmental engineering fourth edition.

[2] Tharavathy, N.C., Hosetti, B.B. 2003. Biodiversity of algae and protozoa in a natural waste stabilization pond: A field study. J Environ Biol, 24(2), 193-199.

[3] Frank, R.S., Joanne, D. 2003. A handbook of Wastewater Treatment Plant Operations Made Easy: A Practical Guide for Licensure.

[4] Sperling, V.M., Lemos, D.C. 2005, Biological wastewater treatment in warm climate regions, IWA Publishing, London.

[5] Nair, G. 1997. Role of organisms in sewage treatment I: Types of organisms. Proc Acad Environ Biol, 6(1), 19-26.

[6] Ghulam, M., Munir, H.Z. 2012. Associate Professor/Director Farms (Institute of Soil and Environmental Sciences, University of Agriculture, Faisalabad-38040,) Pakistan.

[7] Zulfiqar, A.B., Qaisar, M. 2009. Low-cost municipal wastewater treatment options for use in Pakistan, 15(1).

[8] Chandio, B.A., Abdullah, M. 1998. Proceeding of National Workshop on Quality of Drinking Water, PCRWR, Islamabad, Pakistan.

[9] Saeed, M.M., Bahzad, A. 2006. Simulation of contaminant transport to mitigate environmental effect of wastewater in River Ravi, Pakistan Journal of Water Resources, 10(2), 4-52. 